Open Access

\title{
Foreword by Prof. Dr. Margret Wintermantel, President of the German Academic Exchange Service (DAAD), for the inaugural issue of the Asian Journal of German and European Studies (AJGES)
}

Margret Wintermantel

Correspondence:

praesidentin@daad.de

German Academic Exchange

Service (DAAD), Kennedyallee 50,

D-53175 Bonn, Germany
The launching of a new, highly visible and accessible peer reviewed journal on German and European Studies with a strong Asian perspective provides a twofold reason to celebrate: Not only does this journal constitute a promising and unique new platform for comparative and mutually inspiring scholarship on contemporary Germany, Europe and beyond. AJGES is also one of the many projects so impressively initiated by the Centre for German and European Studies at Chung-Ang University (ZeDES), which I was proud to welcome into the network of DAAD-funded Centres just recently. The fact that you are now reading the inaugural issue of this journal so shortly after ZeDES' official launch is an exceptional sign of the enthusiasm, creativity and initiative that ZeDES has exhibited from day one. A young and dynamic group of scholars working on contemporary Germany and Europe at Chung-Ang University forms the foundation of this Centre and has been active for many years, culminating in a successful application for a highly competitive DAAD funding scheme in 2013. It is thanks to these scholars that this project could be brought to life so confidently and impressively.

ZeDES is the newest member of the DAAD's network of Centres for German and European Studies and the nineteenth Centre to join. Since the programme's conception in 1991, the DAAD has supported and initiated a wide range of Centres in North America, Europe, East Asia and Israel with the help of considerable funds provided by the German Federal Foreign Office. In East Asia, Centres were set up at the renowned universities Peking University in China, the University of Tokyo in Japan and now Chung-Ang University in Korea.

Based at some of the most outstanding institutions of their respective host countries, the Centres focus on exploring issues regarding contemporary Germany in a European context, often acting as beacons for highly topical research relating to Germany both within their regions and beyond. In addition, the Centres' innovative, interdisciplinary teaching programmes provide future generations of scholars and professionals with crucial expertise on Germany and Europe. Thus, the network is equipped with a unique potential: In highlighting the manifold interactions, conversions and links that connect Germany with the rest of Europe and Europe with other parts of the world the Centres, their scholars and their

(c) 2016 Wintermantel. Open Access This article is distributed under the terms of the Creative Commons Attribution 4.0 International License (http://creativecommons.org/licenses/by/4.0/), which permits unrestricted use, distribution, and reproduction in any medium, provided you give appropriate credit to the original author(s) and the source, provide a link to the Creative Commons license, and indicate if changes were made. 
alumni can help form the foundation for a lasting mutual understanding and, ultimately, a peaceful future within Europe and beyond.

This capacity is shared by the journal you are now reading. Its aim is to cast light from a wide array of interdisciplinary and transcultural angles onto Germany and Europe by taking into account uniquely Asian backgrounds and perspectives, all the while considering common values, ideals and goals. Despite the plethora of different political systems, historic developments and societal structures the two continents exhibit, there are nevertheless common challenges that unite Germany and Europe with East Asian countries and the region as whole, ranging from economy to ecology, from individual demographic developments to sustainability and climate change and, not least of all, the internationalisation of higher education.

East Asia is one of the most important regions of origin for international students at German universities. At the same time, universities in East Asia are increasingly being recognized as important host institutions for students and academics from German universities. Adding to this, the number of research collaborations between academics in Germany and Asia has been steadily growing over the past decade, indicated by the rise in joint publications. It is my strong belief, not only as president of the DAAD, the world's largest funding organisation for the international exchange of students and researchers, that we need an ongoing critical and inspired exchange of scientific ideas, perspectives and knowledge across borders and of the current and future scholars producing these ideas in order to be prepared for the challenges and opportunities that lie ahead. It is this exchange of perceptions and insights along with personal experience beyond national boundaries that will help us make the best possible use of present-day prospects and enable us to deal with common crises through dialogue and understanding.

I very much look forward to many exciting, fruitful and inspiring articles and discussions on these very pages and wish the Asian Journal of German and European Studies a successful start and a lasting and prolific future. To paraphrase a Korean proverb: May the words shared in this journal become the seeds of ever growing understanding, inspiration and cooperation between scholars in Europe and Asia and may we continue to create beneficial, sustainable and lasting change through exchange.

April 2015

Prof. Dr. Margret Wintermantel

President, German Academic Exchange Service (DAAD)

Received: 25 June 2015 Accepted: 15 March 2016

Published online: 25 May 2016

\section{Submit your manuscript to a SpringerOpen ${ }^{\circ}$ journal and benefit from:}

- Convenient online submission

- Rigorous peer review

- Immediate publication on acceptance

- Open access: articles freely available online

- High visibility within the field

- Retaining the copyright to your article

Submit your next manuscript at $>$ springeropen.com 